DOI: $10.19195 / 0137-1150.163 .48$

\author{
FILIP KOMBEREC \\ Katedra bohemistiky PF UJEP, Republika Czeska \\ komberec.filip@gmail.com
}

\title{
Prožitek a reflexe stáŕí ve vybraných prózách Bohumila Hrabala ze 70. let
}

\section{Úvod}

Když jsem se zamýšlel nad tím, jakým způsobem je v prózách Bohumila Hrabala pojednáno stáří, uvědomil jsem si, že důležitým tématem se stává především v prózách ze 70 . let, svým způsobem, i když spíše okrajově, se objevuje už v závěru románu Obsluhoval jsem anglického krále (1971), výrazněji v meditativní básnické próze Př́liš hlučná samota (1976), centrálním tématem se pak stává v románu Harlekýnovy miliony (1979). Můžeme uvažovat nad tím, zda bylo objevení tohoto tématu ve zmiňovaných prózách ovlivněno fakty $\mathrm{z}$ autorova života (zda souvisí se zkušeností smrti rodičů a vlastního vážného onemocnění); jisté však je, že došlo k výrazné proměně poetiky směrem od pábitelského období 60 . let $\mathrm{k}$ období, jež bychom mohli nazvat reflexivním a meditativním, popř́padě obdobím, kdy dochází k syntéze epické a lyrické větve autorovy tvorby.

Tématizace stáríí, která se objevuje v prózích psaných stylem proudu dlouhých vět, který je charakteristický pro období, z něhož pochází zkoumaná díla, ${ }^{1}$ souvisí s určitou představou času, respektive s určitou mýtickou představou, na základě níž je možné rozumět smyslu lidského času, a projevuje se v tom, jak postavy prožívají a reflektují svou zkušenost stáří. Je možné vysledovat dvě mýtické představy běhu lidského života: v Př́liiš hlučné samotě je to dynamická a dialektická opozice protikladů mládí a stáří charakterizující kromě individu-

${ }^{1}$ Srov. M. Jankovič, K poetice dlouhých vět Bohumila Hrabala, „Bohemica litteraria” 17, 2014, s. 7-26. 
álního lidského života i dynamiku dějinného vývoje; v Harlekýnových milionech je to tradiční představa lidského života jako kruhu analogického ročním obdobím a jednotlivým měsícům. Haňta, hrdina Přiliš hlučné samoty, žije bud' ve vzpomínkách, nebo svou prací, kterou se rituálně uvádí do situace mimo čas. Marie, stylizovaná postava Hrabalovy matky, která je protagonistkou Harlekýnových milioni̊, žije také především vzpomínkami, a přestože živě a se zájmem vnímá své okolí a dění v domově důchodců, podobně jako Haňta nežije v reálných časoprostorových souřadnicích, protože skutečnost, kterou vnímá, prosycuje natolik svou imaginací, že se její realita stává složitě konstruovanou, nestabilní a výrazně kontrarealistickou fikcí.

Cílem interpretace je ukázat, že tematizace stáří ve zmíněných prózách Bohumila Hrabala souvisí s určitou mýtickou představou vysvětlující plynutí času a jeho smysl, dále že tematizace stáŕí je ovlivněná autorovu poetikou konfrontace (v tomto př́padě konfrontace s mládím), a nakonec popsat, jakým způsobem postavy Haňt'i a Marie zkušenost stáří prožívají a reflektují, a pojmenovat specifické rysy této zkušenosti.

Metodologickým východiskem je především důsledná tematicko-motivická analýza zkoumaných textů (s přihlédnutím $\mathrm{k}$ našemu tématu prožitku a reflexe stáří), jejíž výsledky se snažíme hermeneuticky interpretovat v kontextu dosavadních významných prací věnovaných Hrabalovu dílu.

\section{Ježíš a Lao-c': mládí a stáří ve vztahu konfrontace a komplementarity}

Hrabalova poetika konfrontace ${ }^{2}$ se uplatňuje i ve způsobu, jakým autor tematizuje stáríi. Rád bych tuto myšlenku rozvinul na interpretaci 4. kapitoly Př́li ǐs hlučné samoty, v níž do Haňtovy balírny vstupují postavy Ježíše a Lao-c', které jsou v Haňtově meditaci promýšleny jako radikálně kontrastní, avšak jejich porovnáváním Haňta dospívá k poznání, že dohromady tvoří jednotu v protikladu: život a smrt, počátek a konec, vitalita a existencialita, ${ }^{3}$ mládí a stář́ jsou tak ve vztahu vzájemného konfrontování a zrcadlení; jsou neoddělitelné, poznání jednoho není bez poznání druhého. Jsou to zároveň dva způsoby životní orientace a př́stupu ke skutečnosti, které jsou podle Haňtovy interpretace ovlivněny věkem Ježíše a Lao-c': „poprvně jsem si uvědomil, že je hrozně důležité k poznání jejich myšlení, jak je který stár." ${ }^{, 4}$ Pro přehlednost jsem charakteristiky Ježíše a Lao-c ${ }^{5}$ znázornil do tabulky:

\footnotetext{
2 S. Roth, Hlučná samota a hořké štěstí Bohumila Hrabala, Praha 1993, s. 71, 143.

${ }^{3}$ M. Jankovič, Kapitoly z poetiky Bohumila Hrabala, Praha 1996, s. 102.

${ }^{4}$ Hlučná samota, eds. B. Hrabal, M. Jankovič, Praha 1994, s. 31.

${ }^{5}$ Ibidem, s. 31-36.
} 


\begin{tabular}{|c|c|}
\hline JEŽÍÍS & LAO-C' \\
\hline Jde neustále do kopce & Už stojí na vrcholku \\
\hline $\begin{array}{l}\text { Rozhorlený mladý muž, který chce změnit } \\
\text { svět }\end{array}$ & $\begin{array}{l}\text { Starý pán se rezignovaně rozhlížel a návratem } \\
\text { k počátku si podšíval svojí věčnost }\end{array}$ \\
\hline $\begin{array}{l}\text { Zaklíná modlitbou skutečnost, která směřuje } \\
\text { k zázraku }\end{array}$ & $\begin{array}{l}\text { Velkou Cestou sleduje zákony přírodní a jedi- } \\
\text { ně tak dospívá k učené nevědomosti }\end{array}$ \\
\hline $\begin{array}{l}\text { Kterak je pln rozhorlenosti uprostřed skupiny } \\
\text { mladých mužů a krásných slečen }\end{array}$ & Docela osamocený si hledá důstojný hrob \\
\hline Pořád plný líbezné extáze & $\begin{array}{l}\text { V hluboké melancholii opíral se o hranu mého } \\
\text { koryta s pohrdáním a nezájmem }\end{array}$ \\
\hline $\begin{array}{l}\text { Pln víry dává příkazy a hora se přenáší o kou- } \\
\text { sek dál }\end{array}$ & $\begin{array}{l}\text { Přikrýval můj sklep sítí upletenou z nepolapi- } \\
\text { telného intelektu }\end{array}$ \\
\hline Jako optimistická spirála & Jako bezvýchodná kružnice \\
\hline Plný konfliktních a dramatických situací & $\begin{array}{l}\text { V tichém zadumání uvažoval o neřešitelnosti } \\
\text { morální situace protikladů }\end{array}$ \\
\hline $\begin{array}{l}\text { Tenisový šampion, který právě vyhrál Wim- } \\
\text { bledon }\end{array}$ & $\begin{array}{l}\text { Docela zbědovaný podobal se obchodníkovi, } \\
\text { který při bohatých zásobách vypadá, jako by } \\
\text { nic neměl }\end{array}$ \\
\hline $\begin{array}{l}\text { Krvavá tělesnost všech Ježíšových šifer a } \\
\text { symbolů }\end{array}$ & $\begin{array}{l}\text { Stál v rubáši a ukazoval na fošnu neotesaného } \\
\text { dřeva }\end{array}$ \\
\hline Plejboj & Žlázami opuštěný starý mládenec \\
\hline $\begin{array}{l}\text { Zdvihá imperativně ruku a mocným gestem } \\
\text { zatracuje své nepřátele }\end{array}$ & $\begin{array}{l}\text { Rezignovaně spouští ruce jako přeražené pe- } \\
\text { rutě }\end{array}$ \\
\hline Romantik & Klasik \\
\hline Př́liv & Odliv \\
\hline Jaro & Zima \\
\hline Účinná láska k bližnímu & Vrchol prázdnoty \\
\hline Progressus ad futurum & Regressus ad originem \\
\hline
\end{tabular}

Máme tu rozpracovanou sérii protikladných charakteristik, přičemž na jedné straně stojí mládí, touha měnit svět, dynamika a vitalita a na straně druhé stáŕí, distance, intelektuální reflexe a meditatativní rozvažování nad pomíjivostí života. Mládí a stáří, reprezentované postavami Ježíše a Lao-c', nejsou jen dvěma charakteristikami lidské osobnosti, ale jsou zároveň i vyjádřením specifické filozofie dějin, dialektického vyrovnávání protikladů, pohybu tam a zpět:

Všechno jde současně dopředu a všechno se současně navrací zpět, tak jako dmuchadlo kovářské, tak jako na povel zelených a červených knoflíků na mém presu všechno přeskakuje ve svůj opak a jedině tak na světě nic nekulhá [...] Tak spirála a kruh si v mém zaměstnání odpovídají a progressus ad futurum splývá s regressem ad originem a já to všechno navíc hmatově prožívám, a jsa proti své vůli vzdělán, jsem neštastně štasten a začal jsem ted' snít o tom, že progressus ad originem si odpovídá s regressem ad futurum. ${ }^{6}$

${ }^{6}$ Ibidem, s. 42.

Slavica Wratislaviensia 163, 2016

(C) for this edition by CNS 
Lidský život je tak paradoxem postupu vpřed, který je navracením se k počátku: ,a tak jak jdeš dopředu, současně se navracíš zpátky, ano progressus ad originem je regressus ad futurum." ${ }^{77}$ Pozoruhodnou paralelu k této kontrapozici Ježíše a Lao-c' představuje i zmínka o biblických knihách Piseň pisní a Kazatel: tentýž autor (obě knihy jsou připisovány králi Šalomounovi) se dívá na lidský život ze dvou odlišných životních perspektiv: z perspektivy mladosti (vitality a erotičnosti) a stáŕí (vědomí pomíjivosti a marnosti); knihy jsou dvěma pohledy téhož člověka na život, který se jeví z obou perspektiv zcela odlišně. Teprve dohromady vytváŕejí celkový pohled na lidský život, kterým je „úměra mezi knihou jeho mladosti, Písní písní, a výsledkem jeho pohledu starého pána, knihou Kazatel."8

\section{Vyhazov z milované práce: zastavení Haňtova „času”}

Haňta třicet pět let pracuje ve starém papíru a v době, kdy vypráví svůj příběh, má rozhodně blíže k Lao-c'; ke zkušenostem svojí mladosti se obrací ve vzpomínce a ze své současné perspektivy jí teprve zpětně rozumí v úplnosti. V Haňtově osobní zkušenosti se protiklad mezi mládím a stářím projevuje v tom, že mladý člověk pečuje o svůj vnější obraz: ,já když jsem byl mlád, tak jsem taky míval o sobě krásné představy", ${ }^{9}$ ve stáŕí je člověk naopak povolán k péči o svou niternost a o svůj obraz před sebou samým.

Haňtova přítomnost i budoucnost, jeho posvátný, rituální čas končí, když je vyhnán z rajské zahrady své balírny; tím se stává součástí staré doby, je nahrazen brigádou socialistické práce. ${ }^{10}$ Haňta je plně závislý na své práci, v níž se prostřednictvím rituální tvorby a rozjímání dostává mimo čas; z této perspektivy můžeme rozumět i Haňtovým snům o uměleckém tvoření v důchodu ${ }^{11}$ (v čemž je mu vzorem a inspirací jeho strýc), i úsilí Mančinky, jež svůj neštastný osud překonává tím, že svůj život přetvář́i v umělecký artefakt: jsou to pokusy, jak popřít plynutí času, onen „času vztek”, pomíjení i nezbytné involuční změny ${ }^{12}$ a vlastní pád.

\footnotetext{
${ }^{7}$ Ibidem, s. 71.

${ }^{8}$ Ibidem, s. 73.

${ }^{9}$ Ibidem, s. 71.
}

10 Jde o vystřídání jednoho př́stupu k práci novějším; dochází ke konfrontaci těchto odlišných způsobů práce: ,jinačí způsoby myšlení... že je konec všem těm mým kamarádům baličům a konec i můj, protože všichni my staří baliči jsme byli proti své vůli vzdělan... a každý jsme ty knihy četli v bláhové naději, že jednou si něco přečteme, co nás kvalitativně změní [...] definitivně je konec starých časů, že skončila epocha, ve které se dělník na kolenou a v prstech a dlaních matroval s materiálem, jako by s ním zápasil, dával jej na lopatky, tak každý starý typ dělníka byl od práce zbědovaný a umazaný, protože si musel pustit práci na tělo" (ibidem, s. 55).

11 Ibidem, s. 13-14, 20-21.

$12 \mathrm{~K}$ tématu fyzických a psychických involučních změn ve stáří srov. P. Říčan, Cesta životem, Praha 2014, s. 333-344. 


\section{Lidský život jako kruh}

V Harlekýnových milionech je představa lidského života znázorněna na první pohled nikoliv polaritou vzájemných kontrastů mládí a stáŕí (jak tomu bylo při konfrontaci symbolických postav Ježíše a Lao-c' v Př́liš hlučné samotě), ale kruhem barokních soch jednotlivých měsíců a ročních období. Tento kruh soch při četných návštěvách zámecké zahrady iniciuje meditace vypravěčky Marie nad uzavírajícím se „kruhem” jejího vlastního života:

Stála jsem okouzlena poznáním, že jsem rozřešila tajemství všech soch v celku ... nalevo socha Jara, celá zalitá milostným profilem, na čele růži, s růžemi ve vlasech, s růžemi kolem klína a prsů, kolem boků, růže tak kladené, aby tím víc vynikla nahota krásného jarního těla ... a vedle socha Léta, ve vlasech nahé ženy pšeničné klasy, u stehna pšeničný snop, v prstech klasy, ve druhé ruce srpek, kterým uškubává z pšeničného pole klasy, samé klasy nesmrtelné pšenice, která je obrazem nekonečna, která neustále okřívá přítomností ... a na druhé straně balustrády sochy dvou mužů, Podzim, proti nebi muž držící ohromný pískovcový hrozen vína, druhou rukou drtí ten hrozen, štáva z něj kape na lasturu, která je skleněná, a Mílek, božský pískovcový andělíček hltá mocnými doušky štávu ... a pak poslední socha starce, Zimy, která uzavírala cyklus přírody a člověka, socha starce, který se podobá všemu tomu, čím jsem byla obklopena $\mathrm{v}$ domově důchodců, $\mathrm{v}$ bývalém hraběcím zámku, ve kterém jsem dneska uviděla všechny pískovcové fáze, kterými jsem prošla já a ti ostatní, abych zalitovala, že když jsem byla mladá, zapomněla jsem na lásku, která mi protekla mezi prsty dř́iv, než jsem se nadála ... Ale co je život? ${ }^{13}$

Podobně jako Haňta nedospívá k dobrovolné radostné rezignaci Jana Dítěte ze závěru románu Obsluhoval jsem anglického krále ${ }^{14}$ vypravěčka nedokázala všechny absurdní momenty začlenit do celistvého sebeporozumění vlastnímu životnímu př́iběhu. Za prvé představa života jako přírodního cyklu neodpovídá úplně její zkušenosti (je to do jisté míry idealizovaná a zcizená struktura) a za druhé tou sochou z cyklu měsíců, která nejvíce iniciuje vypravěččino přemýšlení o vlastní identitě, je právě socha máje, socha mládí, která jí otvírá cestu k pochopení, kým byla: „Ta socha mladé krasavice s malými prsy a vyzývajícími boky na mne zapůsobila víc než zrcadlo." ${ }^{15}$ První setkání se sochami v zahradě, především

13 Nymfy v di̊chodu, ed. B. Hrabal, M. Chlíbcová, Praha 1994, s. 324-325.

${ }^{14}$ V Obsluhoval jsem anglického krále jsme svědky uzavření se kruhu vypravěčova života, radikálního přerodu z „pólu ježíšovského”, vitálního, ambiciózního, hledajícího uplatnění sebe sama ve světě $\mathrm{k}$,pólu lao-c'ovskému”, k pokornému přijetí přítomnosti a samoty, k návratu k počátku vedeném úsilím o poznání, kým člověk byl, což je iniciováno vědomím konce (životem pod úhlem nekonečnosti a věčna). Kruh Jana Dítěte se začal postupně uzavírat, prošel si zkušeností povadnutí, kdy se začal dívat na věci z druhé strany (během „poslední večeře” v internačním táboře) a vstoupil dobrovolně do samoty, když se mu život stal př́ípravou na smrt a meditativním hovorem se sebou samým. Svou životní zkušeností se dopracoval k nadhledu nad sebou samým a k určité moudrosti, z jejíž perspektivy dokáže nahlédnout svůj život i na pozadí nejrůznějších dějinných zvratů jako celek. Důležité je, že v případě závěrečné kapitoly Obsluhoval jsem anglického krále se jedná o dobrovolnou rezignaci, nevynucenou historickým tlakem, na rozdíl od Hlučné samoty a Harlekýnových milionu.

${ }^{15}$ Nymfy v dichodu..., s. 200. 
sochou máje, v níž se zhlíží jako v zrcadle, ve vypravěčce vyvolá vzpomínky na první fyzické projevy stáŕí, které si dlouho odmítala připouštět. Při závěrečném vstupu do zahrady se sochami, když už vypravěčka částečně zbilancovala svůj život, především události po 2 . světové válce, které znamenaly zastavení jejího času, se rozhoduje k celkové meditaci nad svým životem. Nicméně cyklický kruh soch v parku neuspokojuje radikální vypravěččinu otázku „Co je život?”, což znamená, že kruh soch není výstižnou metaforou porozumění jejímu životu, že je přes svou konejšivou přirozenost a uzavřenost narušován zkušenostmi disharmonie, která je předvedena $\mathrm{v}$ závěrečné kapitole $\mathrm{v}$ domě na břehu Labe, $\mathrm{v}$ níž je všechno, co představovalo vypravěččin život, smeteno jako figurky z šachovnice.

\section{Vztah k budoucnosti a život ve vzpomínce}

Vztah k budoucnosti a akceptace přítomnosti se zásadně odlišuje při srovnání Marie a Francina. Francin se orientuje do budoucnosti, očekává zásadní událost, která přinese mír, Marie se vrací stále více do minulosti, i té, kterou sama nezakusila. ${ }^{16}$ Zásadní úlohu při osvětlování prožitého hraje vzpomínka, ve chvíli dospění na práh stáří se orientace obrací k počátku, nazpátek — tato role vzpomínky jako scelování, hodnocení a porozumění dřive prožité zkušenosti je klíčová nejen v Obsluhoval jsem anglického krále, Př́liš hlučné samotě, ale i v Harlekýnových milionech. V této próze tvoří pamět' a imaginativní snění nerozlučnou jednotu, což je vyjádřeno především postavami tří pamětníků vyvolávajících svým vyprávěním živé obrazy. Vzpomínka je moment omlazení: ,jako bychom vzpomínkou byli mladí;" 17 je chvílí jasného pohledu na to, kým člověk byl: „viděli všechno jasně, ten svůj osudový př́iběh docela přesně ozářený a osvětlený, dokonce i vysvětlený;",18 je návratem k počátku: ,a důchodce vrací se nazpět, protože starý člověk už opravdu nemá kam jít, a když, tak nazpátek, do vzpomínek, do srdce života, který kdysi byl realitou zrovna takovou, jako... co?;"19 vzpomínka přemáhá těžkou realitu: „nastavoval svoje čelo jako lodní př́íd, aby vzpomínkou rozrážela nemilosrdné vlny času, jichž př́boj tam dole u řeky ted’ rozbíjel jeden pomník za

${ }^{16}$ Francin: „Snad to bylo tím, že Francin pořád jenom čekal na nějakou zprávu, která ohromí nejen jej, ale celý svět, ale já jsem věděla, že čeká marně, že čeká zrovna tak, jako dnes čekali důchodci na př́íbuzné, kteří ale nikdy nepřišli [...] Asi to také bylo tím, že Francin už od začátku našeho manželství měl trvalou představu, že všechno to krásné nás teprve čeká, že budoucnost, krásná budoucnost to bude, ve které teprve budeme opravdu št’astni, až budeme v penzi..." Ibidem, s. 305. Marie: „Já jsem pochodovala vytrvale na místě, vydupávala jsem svými kroky další sestup k mrtvým lidem, kteří kdysi žili v městečku, ve kterém se opravdu zastavil čas [...] Ale zestarali jsme, a tak jsme zůstali takoví, jací jsme byli, když válka skončila, dokonce já jsem se posunula někam do minulého století, které mi vstávalo z mrtvých. [...] Tady v tomhle zámku jsem každý den žila v tajemství, ve vrstvách lidských osudů, lidí, kteří už dávno byli pochováni [...] městečka, tam, kde je živé pro nás to, co už tam k vidění není.” Ibidem, s. 308.

17 Ibidem, s. 217.

18 Ibidem, s. 223.

${ }^{19}$ Ibidem, s. 255. 
druhým...,"20 vzpomínky mohou být konejšivým lékem: „Tak nějak si člověk má vybírat z života a vzpomínek jenom to, co je světlé, co jej těší, dokonce ani není pravda, ale na co se tak dlouho věríi, až se to stane..."21

\section{Nešt’astně štastná láska a vlastní minulost jako náročně konstruovaná a nestabilní fikce}

Pro Harlekýnovy miliony je příznačný radikální obrat do minulosti, do vzpomínky, kdy teprve s tímto odstupem se osmysluje prožité. Tři radikální „akordy” signalizují zastavující se čas vypravěčky: destrukce starého hřbitova, umírání a smrt strýce Pepina a nesmyslnost domu u Labe). Pro stáŕí je typická zamilovanost do toho, co již není; vzpomínka na „neštastně št’astnou lásku” a „krásné neštěstí neopětované lásky", sentimentálně elegický cit vyjádřený na jedné straně narkotizující melodií Harlekýnových milionů a na straně druhé tentýž cit v bakchantickém prožitku důchodkyň evokovaný „,antickým polobohem” doktorem Holoubkem a jeho skladbami: 22 jsou to dvě strany téhož prožitku vyplývajícího z konfrontace mládí a stáří. Oživlá mrtvola strýce Pepina je nejhlubším vyjádřením paradoxu uplývajícího a prožitého času, který zůstává živý ve vzpomínce (živý jako spící království v pohádce o Šípkové Růžence, kterou vzpomínky můžou na čas oživit; i tak můžeme rozumět podtitulu a žánrové charakteristice ,pohádka": oživení starého času, jenž se zastavil, je kříšením mrtvoly) ${ }^{23}$, je to čas, který více není, než je, už není skutečností, ale zpětně náročně konstruovanou a velmi nestabilní fikcí.

\section{Závěr}

Téma stáŕí je významným tématem obou interpretovaných próz; pro hlavní postavy je charakteristický obrat do minulosti a do vzpomínky, kritický a distancovaný vztah k současnosti a téměř žádné očekávání od budoucnosti — pro

${ }^{20}$ Ibidem, s. 314 .

${ }^{21}$ Ibidem, s. 315.

22 „Ve zpomalené dionýsovské slavnosti, tančící nymfy v důchodu, plného ale toho samého žáru jako za starých časů, za kterých všechno to krásné i surové bylo dopřáno jen krásným mladým lidem, polobohům, bohům [...] kdy jim došlo, že jediné, co má na světě cenu, že je láska, nešt’astná láska, která je vším pro každu mladou ženu, že ten hudební skladatel prožil a zapsal př́iběh své lásky, která ale už od něj dávno odešla, která se mu stala taky, když byl mlád, že tuhle skladbu mohl napsat, teprve až když pochopil, že už je starý, takovou vzpomínku na lásku, která je víc než láska sama... tak nějak zdálky znělo to vyznání, že vzpomínka lásky je silnějšíi.” Ibidem, s. 285-286. V kontrastu k tomu je uklidňující, narkotizující melodie Harlekýnových milionů: „tichou líbeznou sonatinu nějaké laciné barvotiskové lásky” (ibidem, s. 314).

${ }^{23}$ Pohádka se tak v podstatě stává hororem, paradoxní žánrová charakteristika pak může znít „zromantizovaný horor”. Srov. J. Češka, ,Zromantizovaný horor — Hrabalovy „Harlekýnovy miliony" (K literární topografii města), [w:] idem, Průzračnost tvorby v zrcadle literatury, Praha 2014, s. 165-192. 
Haňtu je budoucnost uzavřená, protože byl vyhnán ze svého čas rušícího rituálu a vypravěčka Harlekýnových milionů se kromě reflektování a znovuproživání událostí posledních let obrací do minulosti předcházející její pamět'. Prožitek a reflexe vlastního stáří je pro postavy zásadní zkušeností, která přehodnocuje jejich dosavadní životní směřování a posouvá je k meditaci a uvažování nad životem jako celkem a nad jeho smyslem, $\mathrm{k}$ čemuž slouží dvě metafory iniciující reflexi života jako celku: protiklad opozic mládí a stáŕí v Přiliš hlučné samotě a kruh $\mathrm{v}$ Harlekýnových milionech, v nichž jsou katalyzátorem zkušenosti uplynulého mládí také hudební skladby vyjadřující lyrickou situaci „nešt’astně št’astné lásky”. Mládí a stáŕí jsou v obou prózách ve vztahu konfrontace a komplementarity a stáří se stává př́ležitostí radikálního sebepoznání; stáŕí je spojeno s prožitkem zastaveného individuálního času a projevuje se obratem do vzpomínek, v nichž se život postupnou integrací traumatických či nedořešených zkušeností začíná jevit jako smysluplný celek.

\section{Bibliografie}

Češka J., Průzračnost tvorby v zrcadle literatury, Praha 2014.

Hlučná samota, eds. B. Hrabal, M. Jankovič, Praha 1994.

Hrabal B., Obsluhoval jsem anglického krále, Praha 1990.

Jankovič M., K poetice dlouhých vět Bohumila Hrabala, „Bohemica litteraria” 17, 2014.

Jankovič M, Hrabal, B., Kapitoly z poetiky Bohumila Hrabala, Praha 1996.

Nymfy v di̊chodu, eds. B. Hrabal, M. Chlíbcová, Praha 1994.

Pelán J., Bohumil Hrabal: pokus o portrét, Praha 2002.

Říčan P., Cesta životem, Praha 2014.

Roth S., Hlučná samota a hořké štěstí Bohumila Hrabala, Praha 1993.

\section{Experience and reflection of old age in selected Bohumil Hrabal's novels from the 70s}

\section{Summary}

This study contains an interpretation of two novels written by Bohumil Hrabal, Too Loud a Solitude and Harlequin's Millions, focusing on the poetic rendition of old age on the background of a certain idea about human life as well as an experience and reflection of old age in the consciousness of main characters. In these novels there are two concepts of the run of human life: in Too Loud a Solitude it is a dynamic and dialectical opposition of youth and old age characterizing individual human life, but also the dynamics of historical development; in Harlequin's Millions we can find the traditional concept of human life as a circle analogous to the seasons and months of the year. Haňta, the character of Too Loud a Solitude, is living either through his memories, or through his work, by which he is being ritually placed beyond the framework of time. Marie, the protagonist of Harlequin's Millions, also lives in her memories, and though she emphatically and with interest perceives her surroundings and day to day events in a retirement home, she does 
not live in the real spacetime, because her imagination transforms her reality so much, so that it becomes an intricately constructed and strongly surrealistic fiction.

Keywords: Bohumil Hrabal, 70s Czech fiction, literary representation of youth and old age, metaphors of human life, memory and perception of literary character

\section{Prežitok a reflexie staroby vo vybraných prózach Bohumila Hrabala zo 70. rokov}

Resumé

V tejto štúdii interpretujem dve Hrabalovej prózy, Príliš hlučnú samotu a Harlekýnovy milióny, so zameraním na poetické stvárnenie staroby na pozadí určitej predstavy o l'udskom živote a na prežitok a reflexiu staroby hlavnými postavami oboch diel. V oboch prózach sú dve predstavy vývoje l’udského života: v Príliš hlučné samote je to dynamická a dialektická opozícia protikladov mladosti a staroby charakterizujúca individuálny l’udský život, ale aj dynamiku dejinného vývoja; v Harlekýnových miliónoch je to tradičná predstava l'udského života podobajúceho sa kruhu mesiacov a ročných období. Haňta, hrdina Príliš hlučnej samoty, žije bud' v spomienkach, alebo svojou prácou, ktorou sa rituálne uvádza do situácie mimo čas. Marie, protagonistka Harlekýnových miliónov, žije tiež spomienkami, a hoci živo a so záujmom vníma svoje okolie a dianie v domove dôchodcov, nežije v reálnych časopriestorových súradniciach, pretože skutočnost', ktorú vníma, presycuje natol'ko svojou imagináciou, že sa jej realita stáva zložito konštruovanou a výrazne kontrarealistickou fikciou.

Klúčové slová: Bohumil Hrabal, česká próza 70. rokov, literárna reprezentácia mladosti a staroby, metafory l'udského života, pamät' a vnímanie literárnej postavy 